\title{
PENGARUH LEVEL BOKASHI KOTORAN AYAM DAN TINGKAT KEPADATAN POPULASI TANAMAN TERHADAP PERTUMBUHAN VEGETATIF SORGUM BROWN MIDRIB (BMR)
}

\author{
Olan Lilhaq, D.A. Kaligis*, Ch. L. Kaunang, Rustandi
}

Fakultas Peternakan Universitas Sam Ratulangi Manado, 95115

\begin{abstract}
ABSTRAK
Penelitian ini bertujuan untuk melihat pengaruh perlakuan level bokashi kotoran ayam dan kepadatan populasi tanaman terhadap pertumbuhan vegetatif Sorgum Brown Midrib (BMR). Level bokashi kotoran ayam berturut-turut $\mathrm{A} 1=$ 0 gram; $\mathrm{A} 2=200$ gram; $\mathrm{A} 3=400$ gram dan $\mathrm{A} 4=800$ gram $/$ polybag dengan kombinasi kepadatan populasi tanaman B1 $=2$ tanaman; $\mathrm{B} 2=4$ tanaman dan B3 $=6$ tanaman/polybag. Perlakuan diatur secara faktorial 4 x 3 dengan 3 ulangan pada rancangan dasar Rancangan Acak Lengkap (RAL). Variabel yang diukur terdiri dari panjang daun, jumlah daun dan tinggi tanaman. Hasil penelitian menunjukkan interaksi kedua perlakuan berpengaruh nyata terhadap panjang daun $(\mathrm{P}<0,05)$, tetapi tidak berpengaruh nyata $(\mathrm{P}>0,05)$ terhadap jumlah daun dan tinggi tanaman. Dari hasil penelitian ini pertumbuhan vegetatif yang optimal dari sorgum BMR diperoleh dengan pupuk bokashi 400 g/polybag pada kepadatan tanaman 2 tanaman /polybag.
\end{abstract}

Kata Kunci: Bokashi kotoran ayam, Kepadatan populasi tamanan, Sorgum BMR, Pertumbuhan.

*Korespondensi (Corresponding author) Email : kaligis.david@yahoo.co.id
ABSTRACT

EFFECT OF LEVEL BOKASHI CHICKEN MANURE AND PLANT POPULATION DENSITY ON VEGETATIVE GROWTH OF BROWN MIDRIB (BMR) SORGUM. The aims of this experiment was to study the interaction of bokashi chicken manure and plant population density on vegetative growth of sorghum Brown Midrib (BMR). Level bokashi were A1 $=0 \mathrm{G} ; \mathrm{A} 2=200$ $\mathrm{G} ; \mathrm{A} 3=400 \mathrm{G}$ and $\mathrm{A} 4=800 \mathrm{G} /$ polybag interact with plant population density $\mathrm{B} 1=$ 2 plants; $\mathrm{B} 2=4$ plants and $\mathrm{B} 3=6$ plants/polybag. Treatments were arranged in a $4 \times 3$ factorial with 3 replications based on a Completely Randomized Design (CRD). Variable measured were leaf length of leaf, number of leafes and plant height. The results showed that the interaction of treatment had significant effect on leaf length $(\mathrm{P}<0.05)$, but did not have significant effect $(\mathrm{P}>0,05)$ on number of leafs and plant height. Each treatment gave significant different effect on these both variable $(\mathrm{P}<0.05)$. Based on this results can be concluded that to get optimal vegetative growth of sorghum BMR needs bokashi fertilizer by 400 G/polybag at density of 2 plants/polybag.

Keywords: Bokashi level of chicken manure, plant population density level, growth sorghum, growth. 


\section{PENDAHULUAN}

Dewasa ini dunia pada umumnya termasuk Indonesia diperhadapkan dengan masalah ketersediaan pangan, energi dan air. Pemerintah berupaya mencapai kedaulatan pangan, khususnya komoditi daging merah yang masih pada impor karena relatif lebih murah ketimbang produksi dalam negeri. Tingginya harga produksi dalam negeri disebabkan ternak sapi diberi makan konsentrat yang harganya lebih mahal dan besaing dengan kebutuhan pangan bahkan energy biofuel. Sedangkan di Australia pemeliharaan ternak mengandalkan padang rumput (Abdullah, 2012). Salah satu masalah yang sedang dihadapi Negara Indonesia yaitu keterbatasan areal padang penggembalaan karena semakin banyaknya konversi untuk pembangunan infrastruktur dan pertanian pangan, kendati masih tersedia lahan di areal perkebunan kelapa sebagai alternatif integrasi budidaya hijauan pakan dengan ternak ruminan (Anis et al., 2011., Anis et al., 2015). Sorgum merupakan salah satu tanaman serealia memiliki daya adaptasi lingkungan yang cukup luas, teknik budidaya relatif mudah, sebagai sumber hijauan pakan dan biji-bijian, tersedia sepanjang tahun, toleran tumbuh pada musim kemarau. Sumarno dan Karsono
(1995). Sorgum BMR telah dikembangkan oleh Biotrop dengan kandungan lignin pada daun lebih rendah tetapi kadar gula relatif tinggi (Supriyanto, 2014), sedangkan produksi bahan kering dan bahan organik berturut-turut $58,61 \mathrm{~kg}$ dan 58,65 kg (Koten et al., 2012). Untuk meningkatkan produksi dan kualitas hijauan pakan sorgum dibutuhkan pemupukan yang berorientasi menghasilkan produk yang dapat menjamin keamanan pangan. Pupuk organik termasuk bokashi merupakan salah satu alternatif yang dapat digunakan sebagai penyedia unsur hara yang dibutuhkan untuk pertumbuhan dan produksi tanaman sorgum. Berdasarkan latar belakang tersebut dilakukan penelitian ini bertujuan mempelajari pengaruh level bokashi kotoran ayam dan tingkat kepadatan tanaman terhadap pertumbuhan vegetatif sorgum Brown Midrib (BMR).

\section{MATERI DAN METODE PENELITIAN}

\section{Pembuatan Bokashi kotoran ayam}

Pembuatan pupuk bokashi kotoran ayam mengikuti prosedur menurut (Kusuma, 2012).

1. Tahap pertama pembuatan pupuk bokashi kotoran ayam 


\section{Persiapan bahan :}

Larutan EM4 (1/2 liter) + molasses ( $1 / 2$ liter $)$

+ air dicampur merata.

Siapkan bahan- bahan pengisi :

Kotoran ayam $(100 \mathrm{~kg})+$ dedak halus $(10 \mathrm{~kg})+$ sekam padi $(20 \mathrm{~kg})$, dan kulit kopi (60 kg), + air secukupnya. Semua bahan pengisi dicampur secara bertahap mulai dari kulit kopi, sekam padi, dedak halus dan kotoran ayam. penyediaan wadah sebagai tempat pencampuran larutan EM4, air dan molases, bahanbahan (EM4, air dan molases) dicampur secara homogen selanjutnya Siramkan larutan tersebut secara perlahan sampai merata ke dalam campuran bahan Kulit kopi, dedak halus, sekam padi dan kotoran ayam. Bahan dicampur berulang kali, lakukan hingga kandungan air di adonan mencapai 30 - $40 \%$. Tandanya, bila campuran dikepal, air tidak keluar dan bila kepalan dibuka, adonan tidak buyar. Hamparkan adonan di atas lantai kering dengan ketebalan 15 - $20 \mathrm{~cm}$, lalu tutup dengan karung goni atau terpal selama 2 4 minggu. Pengecekan suhu dilakukan setiap 5 - 6 jam, suhu dipertahankan $40-$ $50^{\circ} \mathrm{C}$. Apabila terjadi peningkatan suhu pada bahan olahan, maka dilakukan pembongkaran dengan membolak-balikan bahan tersebut dengan tujuan agar terjadi penurunan suhu. Pupuk sudah bisa digunakan apabila memiliki ciri yaitu bewarna hitam, gembur, tidak panas dan tidak berbau.

\section{Penyediaan tanah}

Tanah yang digunakan dihancurkan homogen, dikeringkan tanpa sinar matahari selama 1 minggu. Selanjutnya tanah kering tersebut seberat $4 \mathrm{Kg}$ dimasukan kedalam polybag berdiameter $30 \mathrm{~cm}$ setelah terlebih dahulu dicampur dengan pupuk bokashi sesuai perlakuan leel pupuk yang diuji.

\section{Penyiapan benih sorgum BMR}

Biji sorgum disemai dalam wadah yang berisi pasir yang telah disterilkan dengan cara sangrai. Setelah berkecambah dan bertumbuh membentuk satu fitomer dan memiliki daun dewasa lengkap sebanyak 4 helai, tanaman sesuai perlakuan kepadatan populasi dipindahkan ke dalam polybag. Tanaman disiram sebanyak $240 \mathrm{ml}$ per polybag tiap pagi dan petang.

\section{HASIL DAN PEMBAHASAN}

Pada Tabel 1 terlihat interaksi perlakuan level pupuk bokashi 400 gram (A3) sampai dengan 800 gram (A4) per polybag berinteraksi sama baik dengan 
Tabel 1. Rataan Pengaruh Interaksi Perlakuan Level Bokashi Kotoran Ayam dan Tingkat Kepadatan Populasi Terhadap Panjang Daun, Jumlah Daun dan Tinggi Tanaman Sorgum BMR.

\begin{tabular}{ll}
\hline Interaksi Pelakuan & Panjang Daun \\
\hline A1B1 & $64,25^{\text {de }}$ \\
A1B2 & $57,23^{\text {de }}$ \\
A1B3 & $52,86^{\mathrm{e}}$ \\
A2B1 & $76,70^{\mathrm{c}}$ \\
A2B2 & $75,81^{\mathrm{c}}$ \\
A2B3 & $74,47^{\mathrm{c}}$ \\
A2B3 & $83,88^{\mathrm{ab}}$ \\
A3B1 & $84,53^{\mathrm{a}}$ \\
A3B2 & $83,88^{\mathrm{ab}}$ \\
A3B3 & $81,57^{\mathrm{ab}}$ \\
A4B1 & $68,32^{\mathrm{cd}}$ \\
A4B2 & $81,88^{\mathrm{b}}$ \\
A4B3 & $79,36^{\mathrm{b}}$ \\
\hline
\end{tabular}

Keterangan : Superskrip berbeda pada lajur yang sama berbeda nyata $(\mathrm{P}<0,05)$.

semua tingkat kepadatan populasi tanaman dan memberikan hasil jumlah daun terbanyak dan berbeda nyata $(\mathrm{P}<0,05)$ dibandingkan dengan interaksi perlakuan lainnya, termasuk interaksi A4B1. Hasil ini memberikan informasi bahwa pupuk bokashi dalam penelitian ini mampu memenuhi kebutuhan unsur hara pada pertumbuhan vegetatif sorgum BMR. Hasil penelitian sejalan dengan laporan Kurniawan (2016) bahwa penggunaan pupuk organik kotoran ayam sebanyak 400 gram per polybag memberikan hasil bahan kering rumput Brachiaria humidicola tertinggi, namun munurun pada level pemupukan 1200 gram. Bokashi kotoran ayam memiliki kandungan hara makro yang lengkap terutama Nitrogen. Pertumbuhan jumlah daun berkaitan erat dengan peran $\mathrm{N}$ sebagai komponen klorofil, bertambahnya $\mathrm{N}$ dalam tanah berasosiasi dengan pembentukan dan pertambahan jumlah daun tanaman (Kusuma, 2013.). Kandungan unsur hara beberapa jenis pupuk kandang seperti yang berasal dari kotoran ayam adalah $1,00 \% \mathrm{~N}$; 0,80\% P; 0,40\% K, (Setiawan, 2002). Kandungan unsur hara K sekitar 0,40\%, juga berpengaruh dalam proses pembentukan daun, dimana tanaman sangat membutuhkan unsur hara kalium dalam pembentukan karbohidrat sehingga menghasilkan jumlah daun yang banyak (Sucipto, 2010).

Hasil analisis keragaman menunjukkan interaksi perlakuan tidak memberikan pengaruh yang berbeda nyata $(\mathrm{P}>0,05)$ terhadap jumlah daun dan tinggi 
Tabel 2. Rataan Pengaruh Tunggal Perlakuan Level Bokashi Terhadap Jumlah Daun (helai) dan Tinggi Tanaman (cm).

\begin{tabular}{ccc}
\hline Level & Jumlah & Tinggi \\
Bokashi & Daun & Tanaman \\
\hline A1 & $6,94^{\mathrm{c}}$ & $58,91^{\mathrm{c}}$ \\
A2 & $8,66^{\mathrm{b}}$ & $100,74^{\mathrm{b}}$ \\
A3 & $10,97^{\mathrm{a}}$ & $117,57^{\mathrm{a}}$ \\
A4 & $10,15^{\mathrm{a}}$ & $109,92^{\mathrm{ab}}$ \\
\hline
\end{tabular}

Superskrip berbeda pada lajur yang sama berbeda nyata $(\mathrm{P}<0,05)$.

Tabel 3. Rataan Pengaruh Tunggal Perlakuan Tingkat Kepadatan Populasi Tanaman Terhadap Jumlah Daun (helai) dan Tinggi Tanaman (cm).

\begin{tabular}{ccc}
\hline $\begin{array}{c}\text { Kepadatan } \\
\text { Populasi }\end{array}$ & Jumlah & Tinggi \\
B1 & Daun & Tanaman \\
\hline B2 & $9,75^{\mathrm{a}}$ & 99,85 \\
B3 & $9,19^{\mathrm{ab}}$ & 97,68 \\
- & $8,61^{\mathrm{b}}$ & 92,83 \\
& - & - \\
\hline
\end{tabular}

Superskrip berbeda pada lajur yang sama berbeda nyata $(\mathrm{P}<0,05)$.

tanaman. Namun demikian kedua variabel ini dipengaruhi dengan nyata $(\mathrm{P}<0,05)$ secara tunggal oleh kedua perlakuan sebagaimana tersaji pada Tabel 2 dan 3. Level bokashi 400 (A3) dan 800 (A4) gram per polybag menghasilkan jumlah daun terbanyak demikian juga dengan tinggi tanaman tertinggi dan berbeda nyata $(\mathrm{P}<0,05)$ dibanding dengan level lainnya. Pengaruh kedua level tersebut sejalan dengan pengaruhnya terhadap panjang daun (Tabel 2). Kendatipun secara angka terlihat ada perbedaan pengaruh perlakuan kepadatan populasi terhadap jumlah daun tetapi analisis statistik menunjukkan perbedaan yang tidak berbeda nyata
$(\mathrm{P}<0,05)$, demikian juga terhadap variabel tinggi tanaman. Hasil penelitian ini hampir sama dengan hasil penelitian dari Hariadi (2015) yang menggunakan kombinasi pupuk kandang dan Tricho-kompos memperoleh jumlah daun yaitu 9,83-11,69 helai. Siklus unsur hara dan pembentukan struktur tanah yang stabil sangat mempengaruhi banyaknya jumlah daun dalam suatu tanaman. Unsur hara nitrogen berperan dalam membantu pertumbuhan vegetatif tanaman dan menyusun zat hijau daun (Ferguson et al., 2010; Duan et al., 2007). Hasil penelitian ini lebih tinggi dibanding dengan hasil penelitian Pelealu (2002) pada tanaman sorgum yang 
ditanam di lahan marginal dengan menggunakan pupuk orgazet yang mencapai tinggi tanaman $98,08 \mathrm{~cm}$.

\section{KESIMPULAN}

Berdasarkan hasil penelitian ini dapat ditarik kesimpulan bahwa interaksi penggunaan pupuk bokashi dengan level $400 \mathrm{~g} /$ polybag dan tingkat kepadatan 2 tanaman/polybag memberikan hasil yang terbaik pada panjang daun. Sedangkan interaksi kedua faktor tersebut tidak memberikan pengaruh pada jumlah daun dan tinggi tanaman.

\section{DAFTAR PUSTAKA}

Abdullah L. 2012. Meracik peluang bisnis inovatif pada komoditi tanaman dan hijauan pakan. Jurnal Pastura 12 (1): $1-7$

Anis, S. D., M.A. Chozin, S. Hardjosoewignyo, M. Ghumalahdi, dan Sudrajat. 2011. The effects of heigth and interval of defoliation on productivity and nutrient content of Brachiaria humidicola (Rendle) Schweick. Jurnal Agronomi Indonesia. Vol. XXXIX (3): 217-222.

Anis, S. D., D.A. Kaligis, dan S. Pangemanan. 2015. Integration cattle and grass pature underneath mature coconuts in North Sulawesi, Indonesia. Journal livestock Research for Rural Development. 27 (7). On line: http://www.Irrd.org.
Duan Y. H., Y. L. Zhang, L. Y. Ye, X. R. Fan, G. H. Xu, Q.R. Shen. 2007. Responses of rice cultivars with different nitrogen use efficiency to partial nitrate nutrition. Journal Ann Bot 99: 1153-1160.

Ferguson, B. J., A. Indra Sumunar, S. Hayashi, Meng-Han Lin, YuHsiang Lin, D. E. Reid dan P. M. Gressoff_2010.

Molecular analysis of legume nodule development and autoregulation. Journal Of Integrative Plant Biology. 52 (1): 61 -76

Hariadi, Fifi Puspita, dan Sri Yosewa 2015. Pemberian kombinasi pupuk kandang dengan trichokompas terhadap pertumbuhan tanaman Sorgum (Sorghum bicolor.L) jom Faperta Vol 2 No 1 Februari 2015.

Koten. B. B., R. Dj. Soetrisno, dan B. Suwignyo. 2012. Produksi tanaman sorgum (Shorgum bicolor L. Moench) varietas lokal rote sebagai hijauan pakan ruminansia pada umur panen dan dosis pupuk urea yang berbeda. Buletin Peternakan Vol 36 (3) : 150-155.

Kusuma, M. E., 2012. Pengaruh Beberapa Jenis Pupuk Kandang Terhadap Kualitas Bokashi. Jurnal Ilmu Hewan Tropika Vol 1. (2): 41-46

Kusuma, M. E., 2013. Pengaruh pemberian bokashi terhadap pertumbuhan vegetatif dan produksi rumput gajah (Pennicetum purpureum). Jurnal Ilmu Hewan Tropika Vol 2 (2): 40-45.

Kurniawan, D., S.D. Anis, Rustandi, dan W.B. Kaunang. 2017. Pengaruh 
umur pemotongan dan level pupuk organik terhadap pertumbuhan vegetatif rumput Brachiaria humidicola. Jurnal Zootek Vol 37 (2): 259-267.

Pelealu, J. J. 2002. Biofertilisasi Micoriza Arbuscular Vasicular Dalam Pupuk Organic Pada Varietas Sorgum (Sorghum Bicolor L. Moench) Di lahan Marginal Perkebunan Kelapa. Disertasi Universitas Airlangga. Surabaya.

Setiawan. A. I. 2002. Memanfaatkan Kotoran Ternak. Penebar Swadaya. Jakarta.
Sucipto. 2010. Efisiensi cara pemupukan terhadap pertumbuhan dan hasil beberapa varietas sorgum manis (Sorgum bicolor L.Moench). Jurnal Embryo 7(2) : 67-74.

Supriyanto. 2014. Sorgum Development To Support Food, Feed, Fuel, Fiber And Other Industries. Seameo Biotrop 2014.

Sumarno dan S. Karsono. 1995. Perkembangan produksi sorgum di dunia dan penggunaanya. Iptek Tanaman Pangan Vol 6(2): 257269 